\title{
PEMBERIAN NAMA ANAK DALAM SUDUT PANDANG BAHASA
}

\author{
Nur Rini ${ }^{1}$, Sri Rahayu Zees ${ }^{2}$, dan Pandiya ${ }^{3}$ \\ ${ }^{1}$ Politeknik Negeri Semarang, Jurusan Administrasi Bisnis \\ ${ }^{2,3}$ Politeknik Negeri Semarang,Jurusan Akuntansi \\ E-mail: ${ }^{1}$ nurrinigg@gmail.com
}

\begin{abstract}
Name is an important part of someone's life, it is an identity. However, nowadays a name likely does not reflect the owner's origin or nation. In Indonesian culture context, naming children is a meaningful moment for parents. This qualitative study was intended to describe how parents name their children. It involved 80 respondents; they were Semarang City citizens who had children. The data were collected by distributing questionnaires and conducting interview. Most respondents were Javanese, Moslem, born between 1950s and 1960s, and graduated from high school. The respondents liked combining words from two or more different languages to form their children' names. There were very few parents using Indonesian words only. The languages involved in forming names are Arabic, Javanese, English, Chinese, Sanskrit, Indonesian and Balinese. Moslems tend using Arabic to name their children. Almost all names had meanings. The meaning depends on the giver or the one who named the children. The same names might have different meanings.
\end{abstract}

Key words: naming children, Javanese, name, Semarang parents

\begin{abstract}
Abstrak
Nama memiliki arti yang penting bagi kehidupan seseorang, nama adalah identitas. Namun, terdapat kecenderungan, nama tidak menunjukkan daerah asal atau identitas bangsa pemilik nama. Dalam konteks budaya Indonesia, pemberian nama anak adalah sebuah momentum yang sangat berarti bagi orangtua. Penelitian kualitatif ini bertujuan menerangkan bagaimana orang tua memberi nama anak mereka dari sudut pandang bahasa. Responden penelitian ini adalah 80 warga kota Semarang yang memiliki anak. Data dikumpulkan dengan cara membagikan kuesioner dan wawancara mendalam. Sebagian besar responden bersuku Jawa, beragama Islam, lahir di tahun 1950an hingga 1960an dan lulusan sekolah menengah atas. Ditemukan bahwa para orangtua berkencendungan mengkombinasikan kata-kata dari dua atau lebih bahasa yang berbeda dalam membentuk nama anak mereka. Bahasa yang digunakan yaitu bahasa Arab, bahasa Jawa, bahasa Inggris, bahasa Cina, bahasa Sanskerta, bahasa Indonesia, dan bahasa Bali. Orang tua yang memeluk agama Islam berkecenderungan kuat menggunakan bahasa Arab dalam penamaan anak mereka. Hanya beberapa saja yang menggunakan kata-kata bahasa Indonesia dalam penamaan anak-anak mereka. Hampir semua nama memiliki nama. Makna suatu nama tergantung dari makna yang diberikan oleh pemberi nama. Nama yang sama terkadang memiliki makna yang berbeda.
\end{abstract}

Kata kunci: penamaan anak, nama anak suku Jawa, orang tua Semarang

\section{PENDAHULUAN}

"Nama” merupakan sesuatu yang istimewa tidak saja bagi orang tua ataupun pemilik nama, tapi juga bagi orang-orang dekat dan terdekat seperti rekanan bisnis, kolega, dan sesama anggota asosiasi profesi. Suatu sistem/pola budaya 
pemberian nama pada anak oleh warga Kota Semarang merupakan suatu ciri khas bagi warga Kota Semarang, disamping ciri khas yang lain; seperti makanan, motif batik, seni bangunan rumah/arsitektur, dan lain-lain. Keragaman warga Kota Semarang merupakan daya tarik tersendiri bagi para wisatawan domestik dan asing/manca-negara, dan juga para peneliti khususnya pada bidang sosial budaya.

Kota Semarang memiliki banyak keragaman, khususnya di bidang keagamaan atau sistem keyakinan, dengan pemeluk agama Islam sebagai mayoritas, dan penduduk pada umumnya yang terdiri dari orang Jawa/Suku Jawa yang menggunakan Bahasa Jawa sebagai bahasa sehar-hari. Juga terdapat komunitas Tionghoa yang sudah membaur erat dengan penduduk setempat dan menggunakan Bahasa Jawa dalam berkomunikasi sejak ratusan tahun yang silam. Hal ini ikut membentuk dan mempengaruhi sistem budaya warga Kota Semarang dalam pemberian nama pada anak.

\section{Tinjauan Pustaka}

Budaya merupakan sistem pengetahuan yang meliputi sistem ide atau gagasan yang terdapat dalam pikiran manusia, sehingga dalam kehidupan seharhari, kebudayaan itu bersifar abstrak. Sedangkan perwujudan kebudayaan adalah benda-benda yang diciptakan oleh manusia sebagai makhluk yang berbudaya, berupa perilaku dan benda-benda yang bersifat nyata, misalnya pola-pola perilaku, bahasa, peralatan hidup, organisasi sosial, religi, seni, dan lain-lain, yang kesemuanya ditujukan untuk membantu manusia dalam melangsungkan kehidupan bermasyarakat. Dengan demikian masalah "pemilihan dan pemberian nama pada anak" oleh orang tua sangat terkait erat dengan budaya suatu kelompok masyarakat, yang tentu saja bersinggungan dengan agama atau sistem keyakinan.
Mengkaji masalah "nama” anak atau seseorang tidak terlepas juga dari aspek bahasa. Banyak pakar bahasa berpendapat bahwa bahasa merupakan aspek yang sangat penting dalam kehidupan manusia, bahkan kehidupan suatu bangsa, negara, dan kehidupan global. Dengan demikian bahasa selalu ada dan hadir pada setiap masa atau waktu, dan pada semua lapisan kehidupan masyarakat.

Para ilmuwan juga sangat membutuhkan kehadiran dan keberadaan suatu bahasa, karena pada hakekatnya semua cabang keilmuan adalah ilmu Bahasa. Hal ini disoroti oleh James $\mathrm{R}$ Danis (1976: 67) sebagai berikut:

Almost all of what we customarily cal Il 'knowledge' is language, which means that the key to understand a subject is to understand its language. In fact, that is rather akward way of saying it, since it implies that there is such as thing as a subject which contains 'language'. It is more accurate to say that what we call a subject is its language. That is biology (for example), other than words? If all the words that biologists use were substracted from the language, there would be no biology.............. This means, of course, that every teacher is a language teacher.

Bahasa sebenarnya juga sebagai media untuk memahami dan mengetahui latar belakang, kebiasaan, budaya, aktivitas, dan norma atau nilai-nilai suatu bangsa. Hal ini dinyatakan oleh Gladys G Doty dan Janet Ross (1973: 151) sebagai berikut: "People's speech does reflect their background, their activities, and the values they hold; thus we can learn much about a people by looking at their language"

Pakar bahasa juga menyatakan bahwa bahasa adalah suatu media untuk mewujudkan hubungan antar manusia dan sebagai perwujudan transaksi sosial antara individu satu dengan yang lain. Bahasa dipandang sebagai media penciptaan dan penjaga atau pemelihara hubungan sosial. 
Hal ini dinyatakan oleh Jack C Richards dan Theodore S Rodgers (1992: 17) sebagai berikut:

It sees language as a vehicle for the realization of inter-personal relations and for the performance of social trans-actions between individuals. Language is seen as a tool for the creation and maintenance of social relations.

Pujangga besar Inggris William Shakespeare memberikan suatu pertanyaan besar "What is the name?" Nampaknya masalah nama bukan merupakan hal yang mendasar, bila dipandang sebelah mata atau setengah hati, atau sepintas lalu. Namun pada hakekatnya, masalah nama adalah sangat bernilai, baik dari segi agama, ataupun sosial budaya, bahasa, dan tradisi. Pernyataan senada disampaikan seorang pakar pemasaran Herbert N Cusson bahwa nama adalah sebutan/panggilan yang paling indah bagi pemiliknya. Dengan demikian sebuah nama adalah sesuatu yang sangat diperhitungkan baik bagi diri sendiri maupun orang lain.

Aspek lain yang tak kalah penting adalah agama. Tidak diragukan lagi bahwa aspek agama sangat berperan pada nama seseorang. Di indonesia ada enam agama besar yang diakui negara; yaitu Islam, Katolik, Kristen, Hindhu, Buddha dan Kong $\mathrm{Hu} \mathrm{Cu}$. Hal ini terkait dengan kitab suci agama yang bersangkutan; yaitu $\mathrm{Al}$ Qur'an, Injil, Wedha, dan Tri Pitaka.

Dalam ajaran Islam dinyatakan bahwa setiap anak tergadaikan kepada akikahnya yang disembelih atas namanya pada hari ketuju, rambut kepalanya dicukur, dan diberi nama. Saat itulah orang tua (ayah ibunya) mempunyai kesempatan memilihkan nama yang indah untuk anaknya. Dalam agama Hindu di Kalimantan Tengah terdapat ritual Hiang Sandah. Ritual tersebut merupakan ritual ucapan syukur keluarga atas pertolongan Sang Ngiang Hiang Sandah membantu ibu dalam melahirkan sekaligus ritual pemberian nama seorang anak (Prajoko, 2011).

Orang Barat pada umumnya memiliki konsep nama yang agak berbeda dengan orang timur (Jack C Richards, Jonathan Hull, dan Susan Proctor, 1998: 2). Di kalangan budaya barat, biasa dikenal adanya nama depan, tengah, dan belakang. Nama belakang biasanya berupa nama ayah, nama keluarga, ataupun nama suami (bagi wanita yang sudah menikah/kawin). Kamus “Cambridge Advanced Learner's Dictionary"(2008) menyebutkan namanama depan yang lazim/populer di kalangan orang barat diantaranya Adam, Alexander, Andrew, Anthony, Benjamin, William untuk nama pria/laki-laki, sedang untuk perempuan/wanita nama depan yang lazim/populer diantaranya adalah Alice, Amy, Ann/Anne, Ashley, Deborah, Ella, Emily, Emma, Georgia, Grace, Susan, Ruth, Rosie, Olivia, Sophie, Valerie.

Seorang pengamat Budaya Lono Lastoro Simatupang (2006) menyoroti masalah pemilihan dan pemberian nama pada anak pada kalangan orang tua akhirakhir ini dengan beberapa hal sebagai berikut:

1. Munculnya nama-nama yang distingtif, atau berbeda dari nama yang lazim digunakan, merupakan penunjuk adanya kesadaran individual yang semakin tinggi di kalangan orang tua. Kondisi sosikultural berubah dan kelaziman pun dilanggar.

2. Individu harus punya identitas yang berbeda dari yang lain. Tidak ada lagi Su-Su.

3. Masalah nama adalah persoalan generasi. Generasi demi generasi muncul. Seiring dengan itu terjadi perubahan kondisi sosiokultural. Mobilitas penduduk makin tinggi. Tingkat pendidikan dan pergaulan sosial semakin berkembang. Itu semua berpengaruh pada pemberian nama.

4. Pandangan soal "kabotan jeneng" atau keberatan nama sudah menipis. Dalam pandangan itu, sebuah nama dianggap mengemban semacam misi. Berat misi 
tergantung pada apa yang terkandung di dalam sebuah nama. Beberapa keluarga muda masih bertoleransi kepada orang tua, mereka yang masih menganut paham "kabotan jeneng" itu.

5. Dalam pemberian nama, ada kecenderungan sebagian orang untuk menghilangkan jejak status sosial. Dengan nama, orang berpeluang untuk masuk ke status sosial lebih tinggi. Dalam "nama baru” itu, ada pergeseran orientasi ke arah aristokratisme. Orientasi tersebut termanifestasikan dalam nama yang unsurnya diambil dari bahasa Sanskerta, seperti Paramita, Raditya, dan sebagainya.

6. Ada pula orientasi ke arah nama asing yang ke"belanda-belanda"an. Pada nama tertentu, harapan yang terkandung dalam nama tidak lagi muncul. Yang terjadi lebih ke arah figur-figur tertentu, seperti Napoleon, dan Washington. Kadang acuannya bukan pada sifat figur tersebut, tetapi lebih pada kata itu sendiri.

7. Perubahan orientasi itulah yang menggeser nama-nama lokal, atau nama-nama yang pernah lazim digunakan. Makna dari nama cenderung menyempit. Pada nama, tak lagi digantungkan harapan. Orang memberi nama lebih untuk "mengejar keindahan bunyi".

Secara umum penelitian ini bertujuan untuk mengetahui sistem/pola budaya Warga Kota Semarang dalam pemberian nama anak dalam sudut pandang bahasa. Manfaat hasil penelitian ini adalah dapat memberikan gambaran kepada pihakpihak yang terkait dengan masyarakat Kota Semarang tentang pola budaya Warga Kota Semarang dalam memberi nama anak mereka dilihat dari sudut pandang bahasa.

\section{METODE PENELITIAN}

Data primer penelitian kualitatif yang diperoleh langsung dari Warga Kota Semarang ini berupa pendapat/opini, pandangan, dan tingkat pemahaman warga Kota Semarang terhadap sistem/pola budaya warga Kota Semarang dalam pemilihan dan pemberian nama pada anak. Kota Semarang saat ini terdiri dari 16 kecamatan, yaitu: Banyumanik, Candisari, Gajahmungkur, Gayam-sari, Genuk, Gunungpati, Mijen, Ngaliyan, Pedurungan, Semarang Barat, Semarang Selatan, Semarang Tengah, Semarang Timur, Semarang Utara, Tembalang, dan Tugu. Pemilihan sampel dilakukan dengan cara "purposive sampling" dengan suatu pertimbangan khusus sesuai sifat penelitian ini, yaitu dengan mengambil lima orang per kecamatan, sehingga jumlah responden terpilih secara keseluruhan mencapai 80 orang. Adapun pengumpulan data dilakukan dengan cara penyampaian kuesioner dan melakukan wawancara kepada 16 responden. Responden yang dipilih memiliki kriteria: sudah berkeluarga (menikah), sudah memiliki anak, dan penduduk Kota Semarang (dibuktikan dengan kepemilikan KTP Kota Semarang).

Analisa data dilakukan secara deskriptif kualitatif, tidak banyak menggunakan perhitungan statistikmatematis. Analisa sistem budaya pemberian nama pada anak dalam sudut pandang bahasa mencakup: 1). Bahasa Daerah (Jawa, Sunda, Batak, Banjar, Bugis, dan sebagainya, 2). Bahasa Indonesia, 3). Bahasa Asing (Inggris, Arab, Yunani, Mandarin, dan sebagainya, dan 4). Kombinasi dua bahasa atau lebih.

\section{HASIL DAN PEMBAHASAN}

Profil responden penelitian ini adalah pemeluk agama yang berbeda, yaitu pemeluk agama Islam, Katholik, Kristen Protestan, Hindu dan Buddha. Sebagian besar responden memeluk agama Islam. Terdapat responden yang lahir pada tahun sebelum 1950 namun ada juga yang lahir di tahun 1980an, sebagian besar lahir pada tahun 1950an dan 1960an. Sebagian besar 
responden bersuku Jawa dan benpendidikan SLTA dan Sarjana.

Dari sudut pandang bahasa warga Kota Semarang dalam pemberian nama pada anak, penelitian ini menemukan bahwa responden memiliki beberapa kecenderungan. Sedikitnya terdapat empat fakta yang tertangkap.

Terdapat kecenderungan yang kuat penggunaan kata yang berasal dari bahasa Arab sebagai salah satu unsur pembentuk nama anak oleh responden yang beragama Islam. Jumlah responden yang menggunakan bahasa asing sebagai satusatunya bahasa untuk membentuk nama anak-anak mereka lebih banyak dari jumlah responden yang menggunakan bahasa Indonesia sebagai satu-satunya sumber bahasa pembentuk nama, jumlah mereka mencapai 10\%. Bahasa asing tersebut adalah bahasa Arab dan bahasa Cina.

Tabel 1

Contoh Nama Anak dalam Bahasa Arab

\begin{tabular}{|c|c|}
\hline $\begin{array}{c}\text { Nama dari Bahasa } \\
\text { Arab }\end{array}$ & Arti \\
\hline Chusnul Chotimah & di akhir yang baik \\
\hline Inadinna Fadhliyah & $\begin{array}{l}\text { Inadinna } \\
=\text { Sesungguhnya; } \\
\text { Fadhliyah = } \\
\text { kesempurnaan; } \\
\text { Kesempurnaan yang } \\
\text { sesungguhnya }\end{array}$ \\
\hline Nailul Authari & $\begin{array}{l}\text { Pencapaian suatu } \\
\text { harapan }\end{array}$ \\
\hline Nur Azizah & $\begin{array}{l}\text { Nur=Cahaya; Azizah= } \\
\text { (=nama ayah/Aziz) } \\
\text { perkasa }\end{array}$ \\
\hline Fathonah & Fathonah $=$ \\
\hline Sholekhatun & $\begin{array}{l}\text { Cerdik/pandai; } \\
\text { Sholekhatun= sholeh }\end{array}$ \\
\hline Achmad Azka & Achmad= yang terpuji; \\
\hline Fariza & $\begin{array}{l}\text { Azka= semakin bersih; } \\
\text { Fariza= ada kaitan } \\
\text { dengan nama ibu (Riza) }\end{array}$ \\
\hline Mohammad Nabil & Mohammad =Nama \\
\hline Fauzan & $\begin{array}{l}\text { Nabi dalam Islam; } \\
\text { Nabil=Cerdas; } \\
\text { Fauzan=Keberuntungan }\end{array}$ \\
\hline Farih Ilham & Farih= senang; \\
\hline Amirullah & $\begin{array}{l}\text { Ilham=petunjuk; } \\
\text { Amirullah= pemimpin } \\
\text { ke jalan Allah }\end{array}$ \\
\hline $\begin{array}{l}\text { Ghani Arifah } \\
\text { Fadilla }\end{array}$ & $\begin{array}{l}\text { Yg memberi nama } \\
\text { teman baik; Arifah= }\end{array}$ \\
\hline
\end{tabular}

bijaksana; Fadila=

Rezeki

Responden yang merupakan orang tua dari anak yang namanya terdapat pada Tabel 1 semuanya beragama Islam. Sedangkan tiga nama yang tercantum pada Tabel 2 merupakan nama dari responden keturunan Tiong Hwa yang beragama Buddha.

Tabel 2

Contoh Nama Anak dalam Bahasa Cina

\begin{tabular}{cl}
\hline $\begin{array}{c}\text { Nama dari } \\
\text { Bahasa Cina }\end{array}$ & \multicolumn{1}{c}{ Arti } \\
\hline Tjia Soan Mei & $\begin{array}{l}\text { Tjia = nama marga; } \\
\text { Soan=perempuan; Mei= } \\
\text { cantik/seksi }\end{array}$ \\
Tjia Soan Ling & $\begin{array}{l}\text { Tjia = nama marga; Soan= } \\
\text { perempuan; Ling= }\end{array}$ \\
& pelita/cahaya \\
Tjia=marga; \\
& Soan=perempuan; \\
& $\begin{array}{l}\text { Ie=diambil dari Sio } \\
\text { (thn,bln,jam kelahiran } \\
\text { diyakini membentuk } \\
\text { karakter) }\end{array}$ \\
\end{tabular}

Sebagian besar responden menyukai mengkombinasikan kata-kata dari dua atau lebih bahasa yang berbeda dalam membentuk nama anak-anak mereka. lebih dari tiga perempat dari jumlah responden mengkombinasikan kata-kata dari dua bahasa atau lebih dalam menyusun nama anak-anak mereka. Kombinasi tersebut ada yang berupa kombinasi kata-kata dari:

a. Dua atau lebih bahasa daerah yang berbeda

b. Bahasa daerah dan Bahasa Indonesia

c. Bahasa daerah dan Bahasa Asing

d. Bahasa Indonesia dan Bahasa Asing

e. Bahasa daerah, Bahasa Indonesia dan Bahasa Asing

Berikut disampaikan contoh-contoh nama yang merupakan kombinasi katakata dari dua bahasa atau lebih dalam menyusun nama. 
Tabel 3

Contoh Nama Anak dalam Dua atau lebih Bahasa Daerah yang Berbeda

\begin{tabular}{ll}
\hline \multicolumn{1}{c}{ Nama } & \multicolumn{1}{c}{ Arti } \\
\hline Ngurah Budiarto & Ngurah = Salah satu kasta \\
Wicaksono & Bali; Budiarto= Budi \\
& pekerti; Wicaksono= \\
Putu Raga & bijaksana (Bahasa Jawa). \\
Renditya & Putu (Bahasa Bali) = \\
& sebutan anak Pertama, \\
& Raga (Bahasa Jawa) $=$ \\
& jasmani/fisik, dan \\
& Renditya = perpaduan \\
& nama ortu. \\
\hline
\end{tabular}

Orang tua pemilik nama tersebut bersuku Bali namun telah tinggal lama di Semarang. Pada nama-nama tersebut tampak paduan dua budaya, budaya Bali yang terwujud pada kata pertama, dan budaya Jawa - terlihat pada kata kedua dan ketiga. Dari hasil wawancara dengan orang Bali tentang kata 'wicaksana' dan 'raga', diketahui bahwa kedua kata tersebut juga merupakan kata dari Bahasa Bali. Pengucapan kedua kata tersebut dalam bahasa Bali dilafalkan secara agak berbeda.

Tabel 4

Contoh Nama Anak dalam Bahasa daerah dan Bahasa Indonesia

\begin{tabular}{ll}
\hline \multicolumn{1}{c}{ Nama } & \multicolumn{1}{c}{ Arti } \\
\hline Ayu Retno & Ayu (Bhs Jawa) = Cantik; Retno (Jawa) = \\
Devianti & $\begin{array}{l}\text { permata; Devi merupakan kata modifikasi } \\
\text { dari Desember (Bahasa Indonesia) }\end{array}$ \\
& Ayu (Bahasa Jawa ) Cantik, Anggraeni \\
Devi Ayu & berasal dari kata Anggek (nama bunga) = \\
Anggraeni & Bahasa Indonesia \\
& Siti (Bahasa Jawa) = Tanah, Budi = \\
Siti Budi & Akal/Pikiran (Bahasa Indonesia, Amaliah \\
Amaliah & - amal berartti perbuatan (Bahasa \\
& Indonesia). \\
& Indah (Bahasa Indonesia) = \\
Indah Kartika & cantik, baik, menarik, Kartika = \\
Pratiwi & logam mulia (Bahasa Jawa \\
& Kuna/Kawi), Pratiwi - Pertiwi = \\
& Tanah Air/Negeri (Bahasa \\
Galang Wahyu & Indonesia). \\
Ismaya & Galang (menggalang = mencari = \\
& Bahasa Indonesia), Wahyu = \\
& Bahasa Jawa (Ajaran Tuhan), \\
& dan Ismaya = (Bahasa Jawa) \\
& adalah nama lain Tokoh Wayang \\
& Punakawan "Semar”. \\
&
\end{tabular}

Responden yang memberi nama anak pada Tabel 4 semua bersuku Jawa dan beragama Islam.

Tabel 5

Contoh Nama Anak dalam Bahasa Daerah dan Bahasa Asing

\begin{tabular}{|c|c|}
\hline Nama & Arti \\
\hline Annisa & Annisa (arab) = Wanita; \\
\hline Kesumaningrum & $\begin{array}{l}\text { Kesumaningrum (Jawa) = } \\
\text { bunga }\end{array}$ \\
\hline Paundra Linggar & $\begin{array}{l}\text { Paundra (Sansekerta) = } \\
\text { senjata pamungkas; } \\
\text { Linggar (Jawa) = pindah }\end{array}$ \\
\hline Annisa Vanya Putri & $\begin{array}{l}\text { Arab \& Jawa: Wanita yang } \\
\text { taat agama \& berhasil, } \\
\text { dermawan }\end{array}$ \\
\hline Kun Jati Satrio & $\begin{array}{l}\text { Kun }(\text { Arab) }=\text { menjadi; Jati } \\
(\text { Jawa }=\text { sejati; Satrio } \\
(\text { Jawa })=\text { kasatriya }\end{array}$ \\
\hline Nur Indah Sulistyani & $\begin{array}{l}\text { Nur (Arab) = Cahaya; } \\
\text { Indah Sulistyani (Jawa) = } \\
\text { perempuan yang indah dan } \\
\text { cantik }\end{array}$ \\
\hline
\end{tabular}

Empat nama pada Tabel 5 terdiri dari kata-kata yang berasal dari bahasa Jawa dan bahasa Arab, sebuah nama (Paundra Linggar) merupakan paduan dari bahasa Sansekerta dan Jawa.

Tabel 6

Contoh Nama Anak dalam Bahasa Indonesia dan Bahasa Asing

\begin{tabular}{|c|c|}
\hline Nama & Arti \\
\hline Nanda Afi Anisa & Nanda (Indonesia) = Anak; \\
\hline & $\begin{array}{l}\text { Anisa }(\text { Arab) = perempuan; Afi } \\
(\text { Arab) = yang pemaaf }\end{array}$ \\
\hline Luppy Febryani & $\begin{array}{l}\text { dari Qur'an 'lutfi' (Arab); lahir } \\
\text { di bulan Februari (Indonesia) }\end{array}$ \\
\hline Rizal Rais Nugroho & $\begin{array}{l}\text { Rizal (arab) = Pemimpin; } \\
\text { Singkatan namaOrtu; Nugroho } \\
\text { (Jawa) = berkah }\end{array}$ \\
\hline
\end{tabular}

Hero Satya Perdana Hero (Inggris) = Pahlawan; setia; Perdana (bahasa Indonesia) yang berarti pertama Grinata $\mathrm{T}$ Satria $\quad$ Grinata $=$ green (Inggris) $=$ hijau, tertata (Indonesia); $\mathrm{T}=$ Huruf inisial nama keluarga ayah; Satria (Indonesia) = bertanggung jawab

Bunga Wardah Kaddihan Fauzi Bunga (Indonesia); Wardah $($ Arab) = bunga mawar; Kaddihan $($ Arab) = seperti kilauan minyak zaitun; Fauzi (Arab) =nama ayah(beruntung) Siti (Arab) =Wanita muslim; Budi (Indonesia) yang berbudi dan beramal 
Penggunaan kata bahasa asing tidak hanya terjadi di Semarang, Man (2012) menengarahi kesukaan penduduk Hong Kong akan penggunaan nama Inggris yang ditambahkan pada nama mereka dan diletakkan sebagai kata pertama. Bahkan kadang kata bahasa Inggris yang dipakai adalah kata yang tidak lazim seperti kata Devil, Whale, Chlorophyll padahal katakata tersebut tidak pernah dipakai sebagai nama diri oleh penutur asli bahasa Inggris.

Tabel 7

Contoh Nama Anak dalam Bahasa daerah, Bahasa Indonesia, dan Bahasa Asing

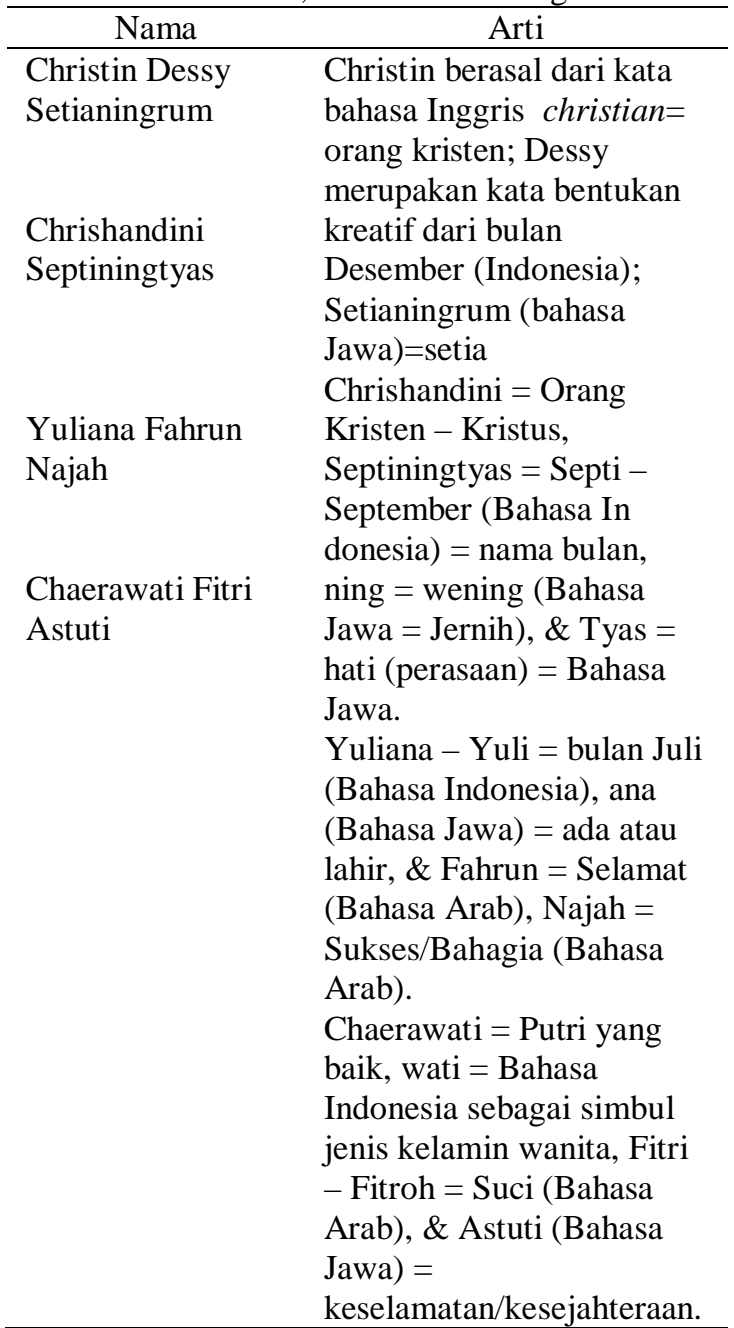

Terdapat kecenderungan warga kota Semarang meninggalkan penggunaan bahasa Indonesia dan Jawa dalam pembentukan nama anak. Orang tua atau pemberi nama memiliki prerogatif yang kuat dalam mengartikan nama yang dibuat. Sebuah nama yang sama dapat dimaknai berbeda oleh responden yang berbeda, sebagai contoh nama Galuh, Responden 26 mengartikan nama putri pertama mereka sebagai keindahan, sedangkan Responden 20 mengartikannya sebagai singkatan dari tanggal tiga puluh. Demikian nama Catur Widianto, oleh Responden 31 dimaknai sebagai ‘yang dibicarakan' (Sewaktu Sang ibu hamil, dia merasa di'catur' oleh para tetangga) bukan menandakan anak yang keempat sebagaimana masyarakat umum mengartikannya. Hal ini senyampang dengan pendapat Tsai (2014) “ Not only does a name bear the identity of a person, it also belies the authority of the namer and the ideology behind the choice of words." Selain sebagai identitas sebuah nama diartikan atau diberi makna oleh yang memberi nama dan ada ideologi yang mendasarinya.

Penelitian ini menemukan hal sebagaimana diungkapkan oleh penelitian Lono Lastoro Simatupang (2006) dan Franz Sartono (2006) yaitu munculnya nama-nama yang distingtif atau unik, atau berbeda dari nama yang lazim digunakan dan sulit dihafal, hal tersebut merupakan penunjuk adanya kesadaran individual yang semakin tinggi di kalangan orang tua. Kondisi sosiokultural berubah dan kelaziman pun dilanggar. Bahkan ada yang mengira pemilik nama anak berikut adalah keturunan Italia seperti nama Segal Mancini Suroso dan Alfino Almero Suroso.

Lebih lanjut Simatupang (2006) menyatakan bahwa individu harus punya identitas yang berbeda dari yang lain, demikian juga dengan penelitian ini. Tidak ada lagi Su-Su. Dalam penelitian ini hanya terdapat 7 nama (dari 188 nama anak) yang memakai awalan 'Su' yaitu Susiana, Sulis, Sulistiani, Sulistiono, Sulistyaningsih dan Suroso (2 nama). Itupun nama Suroso adalah nama orang tua yang dimaksudkan sebagai nama keluarga. Berbeda dari hasil penelitian Amaliana (2016) yang menguak kelompok nama perkawinan campur antara laki-laki orang Bali dengan perempuan suku non-Bali menunjukkan bahwa 
pemertahanan nama depan bagi anaknya dipengaruhi oleh peran ayah sebagai orang yang berasal dari suku Bali.

Pandangan soal "kabotan jeneng" atau keberatan nama sudah menipis. Dalam pandangan itu, sebuah nama dianggap mengemban semacam misi. Berat misi tergantung pada apa yang terkandung di dalam sebuah nama. Hampir semua responden penelitian ini tidak mempermasalahkan keberatan nama. Hanya seorang responden yang memutuskan untuk tidak memberi nama anak yang mengandung arti yang 'berat'. Seorang responden lain juga lebih memilih menggunakan kata-kata dari bahasa Indonesia yang diketahui betul artinya daripada menggunakan kata asing (dalam hal ini Bahasa Arab) yang kurang diketahui artinya.

Ada pula orientasi ke arah nama asing yang ke"arab-arab"an. Hal tersebut dilakukan oleh orang tua yang beragama Islam dan mungkin hal ini merupakan indikasi menguatnya kualitas kehidupan beragama warga kota Semarang.

\section{KESIMPULAN DAN SARAN}

Dapat disimpulkan bahwa penduduk Kota Semarang berkecenderungan mengkombinasikan kata-kata dari dua bahasa atau lebih dalam menyusun nama anak. Sangat sedikit responden yang tertarik menggunakan kata hanya dari bahasa Indonesia. Dalam memberi nama anak mereka mengambil kata-kata dari bahasa daerah (Jawa dan Bali), bahasa Indonesia dan bahasa asing (Arab, Sansekerta, Inggris, dan Cina). Responden pemeluk Islam sangat berkecenderungan memakai kata-kata bahasa Arab sebagai pembentuk nama anak. Makna nama sangat tergantung pada pemberi nama, dua nama yang sama berkemungkinan berarti berbeda.

"Nama" merupakan sesuatu yang bersifat unik, mengandung nilai kesejarahan, nilai fakta, dan sosio kultural suatu masyarakat, walaupun ada kecenderungan mulai bergesernya nama-nama lokal kepada nama-nama asing. Pemeluk agama Islam menggunakan bahasa Arab. Fenomena pemberian nama anak oleh warga Kota Semarang tidaklah berbeda jauh dari hasil penelitian sebelumnya yang dilakukan oleh Simatupang (2006) dan Sartono (2006). Berdasarkan hasil penelitian ini dapatlah diusulkan untuk dilakukannya beberapa penelitian lanjutan seperti budaya pemberian nama pada anak dan sisi ritualnya dalam kehidupan bermasyarakat warga Kota Semarang dengan pelibatan jumlah sampel yang besar dengan memperhatikan proporsi jumlah responden yang mewakili masingmasing variabel (misalnya agama dan suku).

\section{UCAPAN TERIMA KASIH}

Terima kasih kepada Politeknik Negeri Semarang yang telah memberikan dana untuk penelitian ini.

\section{DAFTAR PUSTAKA}

Amaliana, Z.M.Z. (2016). Akulturasi Budaya dalam Pemberian Nama Anak pada Keluarga Perkawinan Campur Antara Suku Bali dan NonBalidi Desa Kalibukbukdan Desa Gerokgak Kabupaten Buleleng (Magister tesis, Undip, 2016). Tesis.

Cambridge Advanced Leaner's Dictionary. (2008). $3^{\text {rd }}$ Edition. Cambridge University Press.

Danis, James R. (1976). Teaching Strategies For College Classroom. Westview Press.

Doty, Gladys G, and Janet Ross. (1973). Language and Life in USA. New York:Harper \& Row Publishers, Third Edition.

Man, Joyce. 2012. "Hong Kong Loves Weird English Names.” The Atlantic, October 1. http://www.theatlantic.com/internati onal/archive/2012/10/hong-kongloves-weird-english- 
names/263103/.(diakses 19 Juli 2018)

Prajoko, A. (2011). Upacara Panca Yadya dalam Kehidupan Beragama. http://www.parissweethome.com/bal i/cultural_my.php?id=7 (diakses 10 Juli 2011)

Richards, J. C., Jonathan Hull, and Susan Proctor. (1998). New Interchange English for International Communication. Cambridge: Cambridge University Press.

Richards, J. C. and Theodore S Rodgers. (1992). Approaches and Methods in Language Teaching, Cambridge: Cambridge Univessity Press.

Sartono, F. (2006). Nenek pun Tak Hafal Nama Cucu. Harian Umum Kompas: Edisi 23 April 2006, hal. 34.

Simatupang, L.L. (2006). Nama Anak Aristokratisme dan Keberatan Nama. Harian Umum Kompas: Edisi 23 April 2006, hal. 34.

Tsai, N. (2014). The translation of names and the fallacy of representation and the creative consequences for literary translation in the ChineseEnglish context. Asia Pacific Translation and Intercultural Studies. Vol. 1, No. 1, 63-81, http://dx.doi.org/10.1080/23306343. $\underline{2014.886398}$ 
